( Entomologica Fennica. 31.VIII.1992

\title{
Aphidoidea of Åland, SW Finland
}

\section{Osmo Heikinheimo}

Heikinheimo, O. 1992: Aphidoidea of Åland, SW Finland. — Entomol. Fennica 3:57-79.

Localities, host plant observations, and collecting dates for 200 species and subspecies of Aphidoidea from Åland are presented. Diagnostic characters are given for 14 of these species, which are new to Finland, and for 2 species new to all the Nordic countries.

Osmo Heikinheimo, Department of Applied Zoology, University of Helsinki, SF-00710 Helsinki, Finland

\section{Introduction}

The province of Åland (Ahvenanmaa in Finnish) is situated in the south-western archipelago of Finland between the southern mainland of Finland and Central Sweden. The first account of aphid species observed in Åland was published by Hintikka (1913), who reported six species. In subsequent publications, the following numbers of aphid species and subspecies have been reported from Åland: Linnaniemi (1935) 4, Nordman (1943) 2, Julin (1959) 1, Kanervo (1960) 1, Krogerus (1960) 1, Thuneberg (1962) 3, Vappula (1962, 1965) 17, Heikinheimo (1963) 1, Eastop (1972) 1, Heikinheimo (1984) 3, Heie (1986) 1 and Heikinheimo (1990) 2, in all 32 species. This surprisingly low number of aphid species from Alland has now been considerably enhanced following the examination of some aphid materials collected in 1960s and 1980s. The previous reports of aphid species referred are treated in more detail below, together with the new, additional aphid records.

\section{Material and methods}

The hitherto unpublished aphid records from Åland are based on several short visits and collecting trips, most of them made by following persons: Kaj Kyrklund (KKY) 2-6.VIII.1980, Ole E. Heie (OEH) 4-7.VII.1982, and Osmo Heikinheimo (HIO) 27-28.V.1982, 18-24.VII. 1982, 28-29.VI.1983 and 29.VI.-8.VII.1984. In addition, wind net trap catches (Heikinheimo 1984) from the period 29.V.-10.XI.1962, a total of 4376 aphid specimens. A total of 146 species and subspecies have been found in this trapped material.

The wind net trap was situated in Jomala, Jomalaby (local code no. 17) in a large open place on a grass field surrounded on different sides by pine forest, a park, a residential garden, and a bank marking the shoreline of a bay with different trees and shrubs. The catches were collected daily and preserved in alcohol.

The collecting localities and their code numbers are presented in the $10 \mathrm{~km}$ square grid ref- 


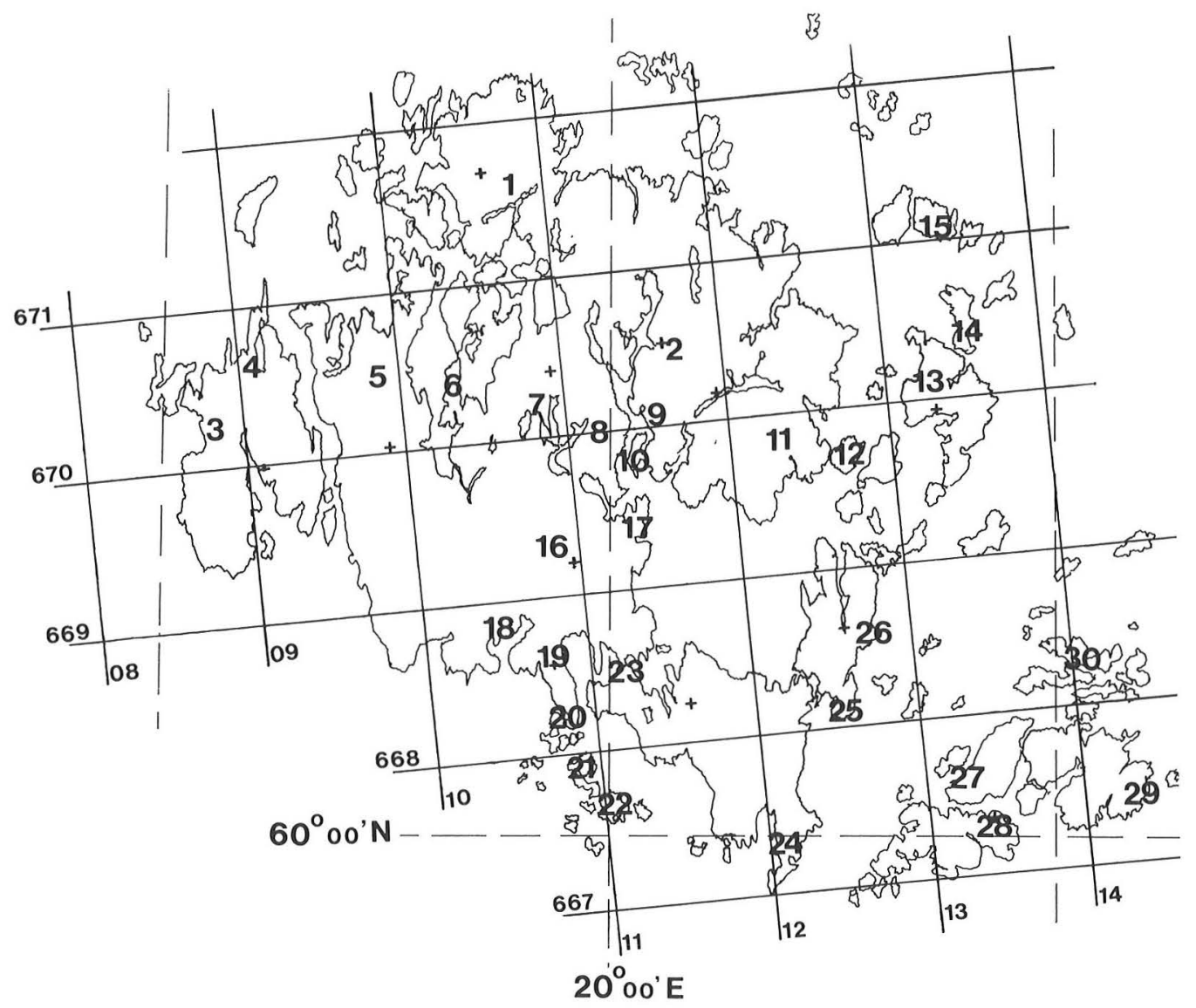

Fig. 1. Collecting localities on the main islands of Åland, with coordinates of $10 \mathrm{~km}$ square grid (Finnish uniform $27^{\circ}$ E grid). -1 = Geta: Östergeta, Bolstaholm; 2 = Saltvik: Centrum; 3 = Eckerö: Storby; 4 = Eckerö: Eköra; 5 = Hammarland: Mörby; 6 = Finström: Husö; 7 = Finström: Centrum; 8 = Finström: Godby; 9 = Sund: Kastelholm N; 10 = Sund: Kastelholm S; 11 = Sund: Finby; 12 = Sund: Bomarsund, Prästö; 13 = Vårdö: Vargata; 14 = Vårdö: Sandö; 15 = Vårdö: Östra Simskäla; 16 = Jomala: Centrum; 17 = Jomala: Jomalaby; 18 = Mariehamn: Käringssund; 19 = Mariehamn: Centrum, Strandnäs; 20 = Mariehamn: Espholm, Ytternäs; 21 = Lemland: Nåtö; 22 = Lemland: Järsö; 23 = Lemland: Lemström; 24 = Lemland: Flaka-Herrö; 25 = Lumparland: Svinö; 26 = Lumparland: Långnäs; 27 = Föglö: Degerby; 28 = Föglö: Kyrkby; 29 = Föglö: Hastersboda; 30 = Föglö: Överö, Bänö.

erence map (Heikinheimo \& Raatikainen 1971, 1981) of the main islands of Åland (Fig. 1).

Aphid species new to Finland have been marked with *, and those new to the Nordic Countries with **. The species have been presented in each family (subfamily) in alphabetical order.

The following abbreviations have been used:

abd = abdominal segment

al = alate viviparous female ant $=$ antennal segment

ant $\mathrm{f}=$ antennal flagellum

apt. = apterous viv. female

Ars = apical rostral segment

$\mathrm{B}=$ basal part of ant VI (V)

$\mathrm{BD}=$ basal diameter in $\mu \mathrm{m}$

$\mathrm{Ca}=$ cauda

$\mathrm{CH}=$ number of hairs on $\mathrm{Ca}$

$\mathrm{HL}=$ max. hair length in $\mu \mathrm{m}$

$\mathrm{Ht} 2=$ 2nd hind tarsal segment

MT $=$ no. of marginal tubercles on abd II-VI 
$\mathrm{PT}=$ processus terminalis

sex. = alate sexupara

SH = number of subsidiary hairs on Ars

$\mathrm{Si}=$ siphunculus

$\mathrm{Si} \varnothing=$ diameter of siphunculus

$\mathrm{SR}=$ number of sec. rhinaria

THR = ratio posterior HL on hind trochanter/ BD of femur

wnt $=$ wind net trap

\section{Aphid species found in Åland}

\section{Phylloxeroidea}

Adelgidae

Pineus pini (Gmelin, 1789)

Brändö 671:17 on Pinus sylvestris 1917-1922, the plants were moved from a nursery in Ekenäs $(\mathrm{N})$ 666:30 (Linnaniemi 1935).

Sacchiphantes abietis (Linnaeus, 1758)

19: Julin (1959) mentioned the report of Lagerheim (1905, ref.).

\section{Aphidoidea}

MindARIDAE

Mindarus abietinus Koch, 1857

10: 30.VI.1983 (HIO) on Abies sibirica.

ThelAXIDAE

Glyphina betulae (Linnaeus, 1758)

Reported from Åland by Hintikka (1913).

Thelaxes dryophila (Schrank, 1801)

Reported from Åland by Hintikka (1913) and Vappula (1962, 1965). 4: 19.VII.1982 (HIO); 30: Nordman (1943).
Anoecidiae

Anoecia corni (Fabricius, 1775)

17: 31.VII.-13.X.1962 5 al in wnt.

Pemphigidae - Eriosomatinae

Eriosoma (Schizoneura) ulmi (Linnaeus, 1758)

Reported from Åland by Hintikka (1913) and Vappula (1962, 1965). Finström, Örnäs 1917 (Linnaniemi 1935). 17: 4-25.VII.1962 21 al and 1.IX.-26.X.1962 7 sex. in wnt. 2: 28.VI.1983 (HIO); 6: 19.VII.1982, 1.VII.1984 (HIO); 10: 30.VI.1983 (HIO); 11: 1.VII.1983 (HIO). On Ulmus glabra.

Tetraneura ulmi (Linnaeus, 1758)

Reported from Åland by Vappula $(1962,1965)$. 17: 3-21.VII.1962 $10 \mathrm{al}$ and 5.VIII.-13.IX.1962 13 sex. in wnt. 6: 19.VII.1982, 1.VII.1984 (HIO). On Ulmus glabra.

Pemphigidae - Pemphiginae

Gootiella tremulae Tullgren, 1925

17: 13.VIII.1962 1 al in wnt.

Pachypappa populi (Linnaeus, 1758)

17: 28.VII.-18.IX.1962 31 al in wnt. 13: 4.VII.1984 (V. Vikberg leg.)

Pachypappa tremulae (Linné, 1761)

Reported from Åland by Hintikka (1913). 17: 21.VII.-26.IX.1962 $7 \mathrm{al}$ in wnt.

Pachypappa spp.

17: 14.VIII.-28.X.1962 135 al in wnt.

Pachypappella lactea (Tullgren, 1909)

Reported from Åland by Hintikka (1913). 17: 24.VII.-15.IX.1962 3 al in wnt. 
Pemphigus bursarius (Linnaeus, 1758)

17: 25.VII.-20.IX.1962 6 al in wnt.

Pemphigus populinigrae (Schrank, 1801)

17: 27.VIII.1962 1 al in wnt.

Prociphilus (Stagona) pini (Burmeister, 1835)

17: 3.VIII.-11.X.1962 6 al in wnt.

Prociphilus (Stagona) xylostei (DeGeer, 1773)

Reported from Åland by Hintikka (1913) and Vappula (1962, 1965). 17: 28.VII.-26.IX.1962 18 al in wnt. 4: 4.VIII.1980 (KKY); 7: 8.VII.1984 (HIO); 18: 4.VIII.1980 (KKY); 28: 30. VI.1984 (HIO). On Lonicera tatarica and L. xylosteum.

Thecabius affinis (Kaltenbach, 1843)

17: 23.VI.-15.VIII.1962 50 al in wnt.

Pemphigidae - Fordinae

Forda formicaria von Heyden, 1837

17: 8-31.VII.1962 6 al in wnt.

Forda marginata Koch, 1857

17: 25.VII.1962 1 al in wnt.

Paracletus cimiciformis von Heyden, 1837

16: 26.III.1959 (A. Nordman leg.).

Drepanosiphidae - Phyllaphidinae

Betulaphis brevipilosa Börner, 1940

17: 24.VI.-5.VII.1962 4 al in wnt. 19: 4.VII.1982 (OEH), 18-21.VII.1982 (HIO). On Betula pendula.

Betulaphis quadrituberculata (Kaltenbach,1843)

17: 21.VI.1962 1 al in wnt.
Betulaphis spp.

17: 24.VI.-22.VIII.1962 698 al in wnt.

Calaphis betulicola (Kaltenbach, 1843)

16: 26.IX.1981 (HIO) on Betula pubescens.

Calaphis flava Mordvilko, 1928

17: 24.VI.-15.VII.1962 4 al in wnt.

Callipterinella calliptera (Hartig, 1841)

4: 29.VI.1983 (HIO); 5: 29.VI.1983 (HIO); 26: 20.VII.1982 (HIO). On Betula pendula.

Callipterinella tuberculata (von Heyden, 1837)

20: 5.VIII.1980 (KKY) on Betula pendula.

Eucallipterus tiliae (Linnaeus, 1758)

17: 26.VI.-15.VIII.1962 11 al in wnt. 6: 19.VII.1982 (HIO); 19: 3.VIII.1980 (KKY); 21: 8.IX.1981 (HIO); 28: 30.VI.1984 (HIO). On Tilia sp.

Euceraphis betulae (Koch,1855)

17: 29.V.-5.VIII.1962 33 al in wnt. 2: 28.VI.1983 (HIO); 3: 5.VII.1982 (OEH); 13: 6.VII.1982 (OEH); 19: 4.VII.1982 (OEH), 18-21.VII.1982 (HIO); 23: 6.VII.1982 (OEH); 29: 20.VII.1982 (HIO). On Betula pendula.

Euceraphis punctipennis (Zetterstedt, 1828)

17: 17.VI.-17.VII.1962 6 al in wnt.

Iziphya leegei Börner, 1940

17: 24.VI.-9.VIII.1962 82 al in wnt. 3: 19.VII.1982, 28-29-VI.1983 (HIO); 6: 19.VII.1982 (HIO); 21: 6.VII.1984 (HIO). On Juncus gerardi, J. lampocarpus and Scirpus maritimus.

Myzocallis coryli (Goeze, 1778)

1: 29.VI.1983 (HIO); 21: 8.IX.1981(HIO); 30: 20.VII.1982 (HIO). On Corylus avellana. 
Myzocallis myricae (Kaltenbach, 1843)

24: 8.VII.1984 (HIO) on Myrica gale.

Phyllaphis fagi (Linné, 1767)

17: 24.VI.1962 1 al in wnt. 10: 30.VI.1983 (HIO) on Fagus sylvatica.

\section{Pterocallis alni (DeGeer, 1773)}

19: 7.VII.1982 (OEH), 18-21.VII.1982 (HIO); 27: 20.VII.1982 (HIO). On Alnus glutinosa.

Pterocallis maculatus (Von Heyden, 1837)

4: 2.VII.1984 (HIO) on Alnus glutinosa.

Subsaltusaphis aquatilis (Ossiannilsson, 1959)

17: 19.VI.1962 1 al in wnt.

Subsaltusaphis rossneri (Börner, 1940)

17: 2-29.VII.1962 3 al in wnt.

Symydobius oblongus (von Heyden, 1894)

17: 24-25.VI.1962 3 al in wnt. 2: 28.VI.1983 (HIO); 6: 1.VII.1984 (HIO); 20: 5.VIII.1980 (KKY), 8.IX.1981 (HIO). 26: 20.VII.1982 (HIO). On Betula pendula.

Therioaphis luteola (Börner, 1949)

17: 9-29.VII.1962 4 al in wnt.

Therioaphis trifolii (Monell, 1882)

17: 15. VIII1962 1 al in wnt.

*Thripsaphis caricicola (Mordvilko, 1914)

17: 25.VI.-11.VIII.1962 8 al in wnt.

The species has also been caught with the wind net trap in Mikkeli ( $\mathrm{Sa}$ ) 684:51, 30.VII.1967, 1 al.

The spatulate empodial hairs, simple dorsal hairs and visible dorsal wax pores are distinct diagnostic characteristics of this species.
Thripsaphis (Trichocallis) caricis (Mordvilko, 1921)

17: 9-31.VII.1962 10 al in wnt.

Thripsaphis (Trichocallis) cyperi (Walker, 1848)

17: 30.VI.-19.VII.1962 4 al in wnt.

Thripsaphis (Trichocallis) verrucosa Gillette, 1917

17: 17.VII.1962 1 al in wnt. 3: 19.VII.1982 (HIO); 29: 20.VII.1982 (HIO).

Tuberculatus (Tuberculoides) annulatus (Hartig, 1841)

4: 19.VII.1982 (HIO); 6: 1.VII.1984 (HIO); 11: 1.VII.1983 (HIO); 21: 3, 6.VIII.1980 (KKY); 29: 20.VII.1982 (HIO); 30: 20.VII.1982 (HIO). On Quercus robur.

DrepanosiPHIDAE - ChaITOPHORINAE

Atheroides serrulatus Haliday, 1839

3: 19.VII.1982 (HIO).

Chaitophorus nigricantis Pintera, 1987

17: 9-18.VII.1962 4 al in wnt.

Chaitophorus populeti (Panzer, 1801)

17: 25.VII.1962 1 al in wnt. 6: 1.VII.1984 (HIO) on Populus tremula.

Chaitophorus tremulae Koch, 1854

2: 29.VI.1983 (HIO); 5: 29.VI.1983 (HIO); 30: 20.VII.1982 (HIO). On Populus tremula.

Periphyllus aceris (Linnaeus, 1758)

17: 27.VI.1962 1 al in wnt. 6: 1.VII.1984 (HIO); 19: 3.VIII.1980 (KKY), 5.VII.1982 (OEH); 28: 30.VI.1984 (HIO). On Acer platanoides.

*Periphyllus coracinus (Koch, 1854)

6: 19.VII.1982 (HIO); 19: 5.VII.1982 (OEH). On Acer platanoides. 
The species has also been collected in Sjundeå (N) 666:34 21.IX.1983 (R. Rosengren leg.), and in Hämeenlinna (Ta) 676:36, 8.VII.1982 (HIO), always attended by ants.

According to Koch (1854) the alatae have occurred early in summer. No alatae have been found in July. The blackish colour, smaller size, habitation on sprouts and petioles eagerly attended by Formica ants are typical for this species when found in their natural habitat.

Periphyllus lyropictus (Kessler, 1886)

27: 20.VII.1982 (HIO) on Acer platanoides.

Periphyllus testudinaceus (Fernie, 1852)

17: 27.VI.1962 1 al in wnt. 19: 26.IX.1981 (HIO), 5.VII.1982 (OEH). On Acer platanoides.

Aphididae - Pterocommatinae

Pterocomma jacksoni Theobald, 1921

6: 19.VII.1982 (HIO) on Salix caprea.

Pterocomma pilosum Buckton, 1879 ssp. konoi Hori, 1939

17: 22.VI.1962 1 al in wnt. 1: 29.VI.1983, 5.VII.1984 (HIO); 10: 3.VII.1984 (HIO). On Salix caprea and $S$. cinerea.

Pterocomma rufipes (Hartig, 1841)

22: 8.VII.1984 (HIO) on Salix pentandra.

Pterocomma salicis (Linnaeus, 1758)

17: 4.VII.1962 1 al in wnt. 4: 2.VII.1984 (HIO); 6: 19.VII.1982 (HIO); 11: 4.VII.1984 (HIO); 22: 6.VII.1984 (HIO). On Salix pentandra.

ApHIDIDAE - ApHIDINAE

Acyrthosiphon caraganae (Cholodkovsky, 1907)

19: 4.VIII.1982 (OEH). On Caragana arborescens.
Acyrthosiphon knechteli (Börner, 1950)

7: 7.VII.1984 (HIO). On Vaccinium uliginosum (Heikinheimo 1990).

Acyrthosiphon malvae (Mosley, 1841) s. lat.

17: 13.VI.-22.VII.1962 3 al in wnt.

Acyrthosiphon pisum (Harris, 1776)

Reported from Åland by Vappula $(1962,1965)$. 17: 22.VI.-8.VIII.1962 42 al in wnt; 2: 28.VI.1983 (HIO); 10: 21.VII.1982 (HIO); 19: 18-22.VII.1982 (HIO). On Lathyrus pratensis, Medicago sativa, Melilotus officinalis and Trifolium medium, T. pratense.

*Anthracosiphon hertae Hille Ris Lambers, 1947 (Fig. 2)

17: 17.VII.1962 1 al in wnt.

The species has also been caught in Mikkeli (Sa) 684:51, 21.VI.1963, 1 al in wnt.

Hille Ris Lambers (1947) described all morphs except the fundatrix from Potentilla anserina, and Prior (1971) described the fundatrix and completed descriptions of other morphs according to the material collected from Potentilla palustris. The shape of antennae, siphunculi and apical rostral segment resemble those of Macrosiphum, but the shape of antennal prominences and the short subtriangular cauda are more similar to those of some members of Metopolophium. The high number of rather long capitate hairs on the abdomen is common with some species of Uroleucon. Pleural areolations (Miyazaki 1987) of the alate are prominent in their size and are distinctly darker than the spinopleural bands and marginal sclerites on the abdomen. Prior (1971) pointed out of some differences between the British (on Potentilla palustris) and Dutch (on P. anserina) specimens. The characteristics of the alate specimens captured in Finland fit well with the British specimens e.g. in having the length ratio siphunculus/cauda more than 4, and in the segmentally broken pigment pattern on the abdomen (Fig. 2g). The species has been found in Norway (Berger), in Sweden (Öland) (Ossiannilsson 1962, 1969b), and in Denmark (Heie 1973) on Potentilla anserina. 


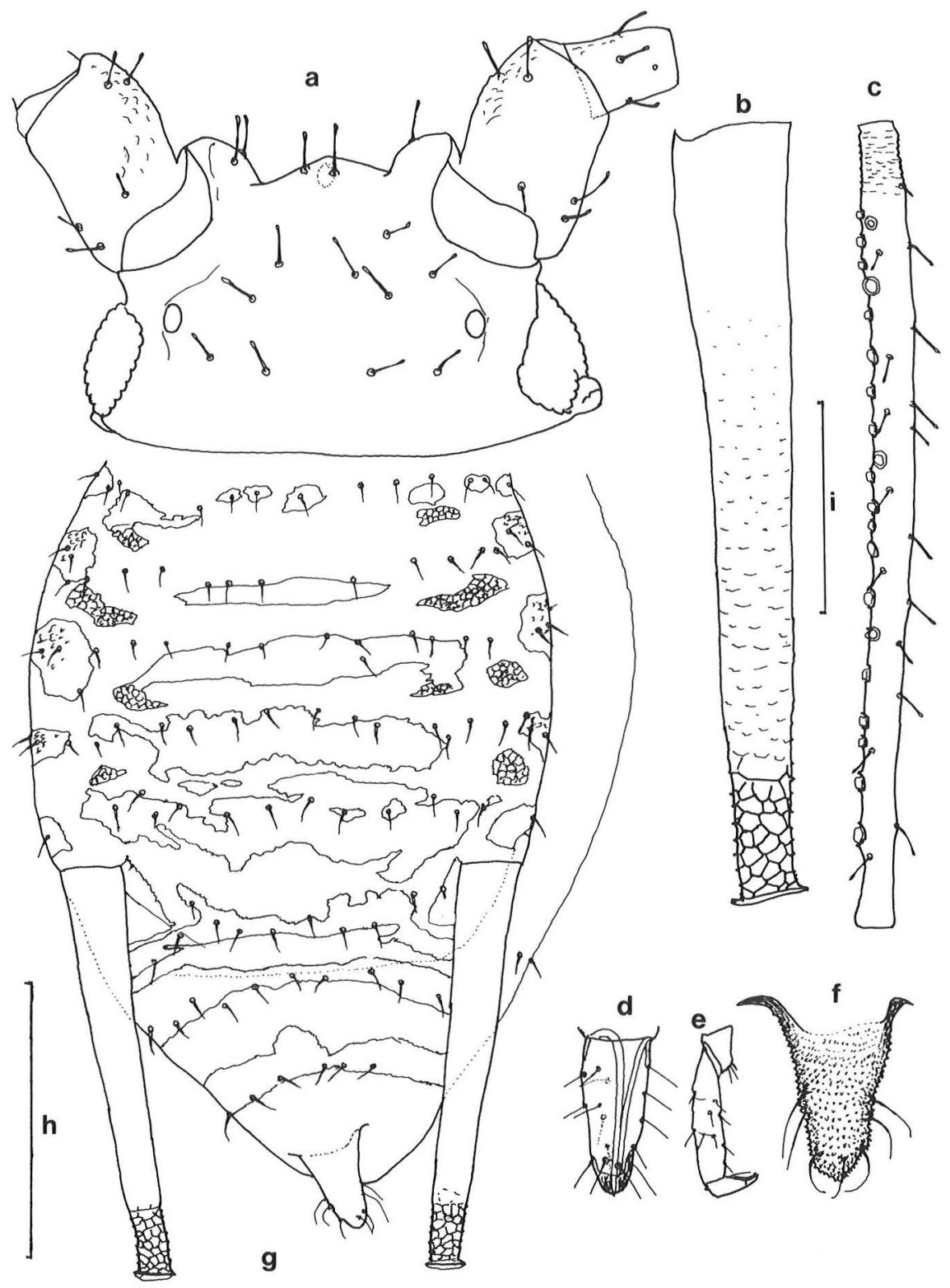

Fig. 2. Anthracosiphon hertae Hille Ris Lambers, 1947. Alate viviparous female. a: head and antennal segments I and II; b: siphunculus; c: antennal segment III; d: apical rostral segment; e: hind tarsus; f: cauda; g: abdomen. Scale $\mathrm{h}: 0.5 \mathrm{~mm}$ for $\mathrm{g}$, scale i: $0.2 \mathrm{~mm}$ for the others.

Biometric data of the al from Aland (measurements in $\mathrm{mm}$ ): Body 2.70; ant f 3.05; ant III 0.88, IV 0.63, V 0.47, B 0.17, PT 0.90; hind tibia 1.68; Si 0.745; Ca 0.17; ars 0.16; Ht2 0.13. HL ant III 35, abd III 37, abd VIII 49, fore head 50. BD ant III 38. Length ratios: ant f/body 1.13;
Si/body 0.28; PT/B 5.29; Si/Ca 4.38; Ars/Ht2 1.23; hind tibia/body 0.62 ; HL ant III/BD ant III 0.92; HL fore head/BD ant III 1.32; HL abd III/ BD ant III 0.98. Number of: SH 9; CH 7; abd VIII 6; SR ant III 21,23, IV and V 0. 
The species lives near the water surface on the runners of Potentilla palustris in bogs (Prior 1971) or on P. anserina.

Anuraphis farfarae (Koch, 1854)

17: 28.VI.1962 $1 \mathrm{al}$ and 11.-28.IX.1962 3 sex. in wnt; 3.IX.1981 (HIO). On Pyrus communis.

\section{Aphis brohmeri Börner, 1952}

17: 8.VII.1962 1 al in wnt; 6: 1.VII.1984 (HIO); 9: 21.VII.1982, 30.VI.1983 (HIO). On Anthriscus silvestris.

Aphis callunae Theobald, 1915

17: 8.VII.1962 1 al in wnt.

Aphis comari Prior \& Stroyan, 1977

17: 25.VII.1962 1 al in wnt.

*Aphis coronillae Ferrari, 1872

17: 28.VI.-1.VIII.1962 27 al in wnt. The species has been also found in Vimpeli (Om) 700:34, 5.VII.1985, 1 al on Trifolium medium.

In a key Brown (1989) has indicated the typical discriminant characters of the al. In the al specimens from Finland the biometric data varied as follows:

Measurements in mm: Body length 1.65-2.10; ant f 1.097-1.314; ant III 0.25-0.35; B 0.1050.130; PT 0.305-0.390; Si 0.24-0.33; Ca 0.1450.190; Ars 0.107-0.125; Ht2 0.105-0.133; BD ant III 20; HL ant III 11-15. Length ratios: Ant f/body 0.57-0.75; Si/body 0.13-0.17; Si/Ca 1.361.98; Ars/Ht2 0.86-1.14. Number of: $\mathrm{CH} 7-9$; SH 2; SR on ant III 4-9, IV 0, V 0. Large marginal tubercles on abd II-VI 8-10.

Aphis craccae Linnaeus, 1758

17: 27.VI.-7.VIII.1962 6 al in wnt.

Aphis epilobii Kaltenbach, 1843

17: 22.VII.-2.VIII.1962 2 al in wnt.
*Aphis euphorbiae Kaltenbach, 1843

17: 25.VI.1962 1 al in wnt.

The species determination is based on the key of Brown (1989).

Biometric data of the captured specimen (measurements in $\mathrm{mm}$ ): Body 2.30; ant $\mathrm{f} 1.45$; ant III 0.42; B 0.158; PT 0.280; Si 0.170; Ca 0.220; Ars 0.115; Ht2 0.150; Bd ant III 22; HL ant III 25. Length ratios: Ant f/body 0.63; Si/ body 0.074; $\mathrm{Si} / \mathrm{Ca} 0.77 ; \mathrm{Si} / \mathrm{Si} \varnothing$ 3.4; PT/B 1.77; Ars/Ht2 0.77; HL ant III/BD ant III 1.13. Number of: $\mathrm{CH} 11$; SH 2; SR ant III 10, 11, IV 0, V 0. There is a small marginal tubercle on abd. III. Pleural areolations, postsiphuncular sclerites and spino-marginal band on abd VII and VIII are dark, marginal sclerites and a spinal patch on abd VI are dusky. Other spinal sclerites on abd are very small or absent.

Aphis fabae Scopoli, 1763 s. lat.

20: Thuneberg (1962). 17: 22.VI.-15.IX.1962 56 al, 3.X.1962 1 male in wnt; 3: 5.VII.1982 (OEH), 19.VII.1982 (HIO); 15: 6.VII.1982 (OEH); 16: 6.VII.1982 (OEH); 19:3.VIII.1980 (KKY), 4.VII.1982 (OEH); 21: 3-5.VIII.1980 (KKY), 6.VII.1984 (HIO); 24: 8.VII.1984 (HIO); 29: 20.VII.1982 (HIO). On Heracleum sp., Rumex crispus, Senecio vulgaris, Tripleurospermum maritimum, Tussilago farfara, Valeriana sp.

Aphis fabae s. str.

Reported from Åland by Kanervo (1960) and Vappula $(1962,1965)$.

Aphis fabae ssp. cirsiiacanthoidis Scopoli, 1763 19: 3.VIII.1980 (KKY), 4.VII.1982 (OEH); 20: 5.VIII.1980 (KKY); 21: 4.VIII.1980 (KKY), 8.IX.1981 (HIO); 25: 20.VII.1982 (HIO); 29: 30.VI.1984 (HIO) (Heikinheimo 1984). On Cirsium arvense, Tripleurospermum maritimum and Viburnum opulus.

Aphis farinosa Gmelin, 1790

3: 1.VII.1983 (HIO); 4: 5.VII.1984 (HIO); 5: 29.VI.1983 (HIO); 19: 7.VII.1982 (OEH); 29: 20.VII.1982 (HIO). On Salix aurita, S. cinerea. 
Aphis frangulae Kaltenbach, 1855 s. lat.

17: 5.VII.-20.IX.1962 6 al in wnt. 24: 8.VII.1984 (HIO) on Satureja vulgaris.

Aphis frangulae s.str.

3: 19.VII.1982 (HIO) on Chamaenerium angustifolium.

Aphis frangulae ssp. beccabungae Koch, 1855

17: 8.VIII.1962 $1 \mathrm{al}$ in wnt. According to the key of Brown (1989).

Aphis hieracii Schrank, 1801

17: 28.VI.-25.VII.1962 3 al in wnt.

Aphis idaei van der Goot, 1912

17: 21.VI.-2.VIII.1962 10 al in wnt. 26: 20.VII. 1982 (HIO) on Rubus idaeus.

*Aphis mammulata Gimingham \& Hille Ris Lambers, 1949

17: 8.-20.VII.1962 2 al in wnt.

Hairs on ant III are very fine, wavy and suberect. Marginal tubercles on abd. I-IV are as large as on abd VII, on V slightly smaller. Marginal, ante- and postsiphuncular sclerites, pleural areolations as well as sclerotic bars on abd are dark. Sclerotic spinal bars on abd. II-V are narrow, on IV and V short, if present, on VI and VII short but broad, on VII long but narrow.

Biometric data of the two specimens captured (measurements in $\mathrm{mm}$ ): Body length 2.55, 2.64; ant f 1.60, 1.62; ant III 0.405; B 0.155, 0.60 ; PT 0.500-0.510; Si 0.275, 0.285; Si / 0.049, 0.059; Ca 0.180, 0.190; Ars 0.150, 0.152; Ht2 $0.142,0.150$; BD ant III 0.025, 0.028; HL ant III 55,$57 ;$ / of MT on abd VII 0.070, 0.078. Length ratios: Ant f/body 0.61, 0.63; $\mathrm{Si} /$ body $0.11,0.17$; PT/B 3.13, 3.29; Si/Ca 1.50, 1.53; Si/Si Ø 4.83, 5.80; Ars/Ht2 1.00, 1.05; HL ant III/BD ant III 1.96, 2.28; MT abd VII //BD ant III 2.5-3.0. Number of: CH 10, 12; SH 2; SR ant III 8, 8; MT 8, 10.

\section{*Aphis mirifica (Börner, 1950)}

17: 27.VII.1962 1 al in wnt.

The species has also been found in Helsinki rural municipality $(N)$ 668:39 (= Vantaa) on
Epilobium montanum, on which apterous males and ovip. were reared. Further observations in Vantaa 10.VIII.1976 (J. Halme leg.), in Rovaniemi $(O b N)$ 747:44 16.VIII.1980 (J. Halme leg.) and in Paltamo (Kn) 714:54 10.VII.1989 (HIO), all three on Chamaenerium angustifolium.

Characters of the specimen from Aland fit well with the descriptions of Brown (1989) and Stroyan (1984). The only minor difference is the number of caudal hairs which is 5 instead of 7 or more.

Biometric data of the al (measurements in mm): Body 1.65; ant f 0.933; ant III 0.250; B 0.130; PT 0.210; Si 0.165; Ca 0.120; Ars 0.108; Ht2 0.107; HL ant III 12; BD III 15. Length ratios: Ant f/body 0.57; Si/body 0.10; PT/B 1.62; $\mathrm{Si} / \mathrm{Ca}$ 1.38; Si/Si $\varnothing$ 3.92; Ars/Ht2 1.01; HL ant III/BD III 0.80; THR 1.0. Number of: $\mathrm{CH} 5$; $\mathrm{SH}$ 2; SR ant III 7, 7, IV 0, V 0; MT 0.

Aphis nasturtii Kaltenbach, 1843

17: 5.VII.-2.VIII.1962 61 al in wnt.

\section{Aphis pomi DeGeer, 1773}

Reported 1917 by Linnaniemi (1935) and Vappula (1962, 1965). 17: 6-15.VII.1962 2 al in wnt. 9: 21.VII.1982 (HIO); 10: 3.VII.1984 (HIO); 17: 5.VII.1984 (Ulla Boman leg.); 28: 30.VI.1984 (HIO). On Malus domestica and Sorbus hybrida.

Aphis pseudocomosa Stroyan, 1972

17: 28.VI.1962 3 al in wnt. 9: 21-22.VII.1982 (HIO). On Lathyrus pratensis. Mentioned from Åland by Heie (1986).

Aphis salicariae Koch, 1855

19: 3.VIII.1980 (KKY); 26: 20.VII.1982 (HIO).

On Chamaenerium angustifolium.

*Aphis sanguisorbae Schrank, 1801

17: 19.VII.1962 1 al in wnt.

The determination is based on the key of Brown (1989). The siphunculi are slightly more slender and longer than represented by Stroyan (1984). 
Biometric data of the specimen captured (measurements in mm): Body 1.85; ant $\mathrm{f} 1.225$; ant III 0.370; B 0.122; PT 0.342; Si 0.230; Ca 0.160; Ars 0.123; Ht2 0.113; HL ant III 8; BD III 23. Lemgth ratios: Ant f/body 0.66; Si/body 0.12; PT/B 2.80; Si/Ca 1.43; Si/Si Ø 6.21; Ars/Ht2 1.09; HL ant III/BD ant III 0.35; THR 0.76. Number of: CH 9; SH 2; SR ant III 6, 7, IV 0, V 0; MT 4.

*Aphis sarothamni Franssen, 1928

17: 24.VI.1962 1 al in wnt.

The key of Brown (1989) has been used for the determination. The dorsal sclerotic pattern of the abdomen differs from that described by Stroyan (1984) in having well developed bands on abd I-III, a short patch on abd VI, and a narrow band on abd $\mathrm{V}$ connected with postsiphuncular sclerites.

Biometric data (measurements in mm): Body 1.88; ant f 1.24; ant III 0.34; B 0.113; PT 0.35; Si 0.22; Ars 0.116; Ht2 0.101; HL ant III 18; BD III 20. Length ratios: Ant f/body 0.66; Si/body 0.12; $\mathrm{Si} / \mathrm{Ca} 1.47 ; \mathrm{Si} / \mathrm{Si} \varnothing$ 6.28; Ars/Ht2 1.15; HL ant III/BD ant III 0.90; THR 0.75. Number of: CH 5; SH 2; hairs on abd VIII 2; SR ant III 8, 9 , IV 2, 4, V 0, MT 6.

Aphis schneideri (Börner, 1940)

17: 29.VI.1962 1 al in wnt. 6: 19.VII.1982 (HIO); 12: 1.VII.1983 (HIO). On Ribes alpinum and Ribes rubrum s. lat.

Aphis sedi Kaltenbach, 1843

3: 5.VI.1982 (OEH), 19.VII.1982 (HIO); 30: 20.VII.1982 (HIO). on Sedum telephium and $S$. hybridum.

Aphis subnitida (Börner, 1940)

21: 4.VIII.1980 (KKY). On Pimpinella saxifraga.

Aphis taraxacicola (Börner, 1940)

15: 6.VII.1982 (OEH). On Taraxacum sp.
Aphis ulmariae Schrank, 1801

17: 5-23.VII.1962 5 al in wnt. 3: 19.VI.1982 (HIO); 29: 20.VI.1982 (HIO). On Filipendula ulmaria.

Aphis urticata Gmelin, 1790

17: 10.VII.1962 2 al in wnt.; 10: 3.VII.1984 (HIO); 21: 5.VIII.1980 (KKY). On Urtica dioica.

Aphis (Toxopterina) vandergooti (Börner, 1939)

17: 21.VII.1962 1 al in wnt. 14: 6.VII.1982 (OEH). On Achillea millefolium.

**Aspidaphium cuspidati Stroyan, 1955 (Fig. 3) 17: 20.VII.-23.IX.1962 7 al in wnt.

Stroyan (1963) described the discriminant characters distinguishing between cuspidati and escherichi (Börner, 1939) alatae. In cuspidati the length ratio PT/B is 1.75-2.2, in escherichi 1.00 1.18. Heikinheimo (1984) reported escherichi from Rovaniemi and Inari. However, only the alate specimen from Inari belongs to escherichi having the ratio PT/B 1.11, whereas in the specimens from Rovaniemi the ratio PT/B varies between 1.44-1.58, and in alatae from Jomala 1.541.75 , respectively. Thus, the alatae from Rovaniemi and Jomala both have interpreted to belong in A. cuspidati. In addition to this, there are some differences in the shape of the aperture of siphunculi (Fig. 3b and d). The figure $5 \mathrm{c}-\mathrm{g}$ in Heikinheimo (1984) represents the alate specimen from Inari belonging to A. escherichi.

Aulacorthum solani (Kaltenbach, 1843)

17: 28.V.1982, 3.VII.1984 (HIO). On Solanum melongena in greenhouse.

Brachycaudus (Acaudus) cardui (Linnaeus, 1758)

Reported from Åland by Vappula $(1962,1965)$. 17: 8.VII.-28.IX.1962 7 al in wnt. 22: 2.VIII.1980 (KKY). On Prunus domestica and Tripleurospermum maritimum. 

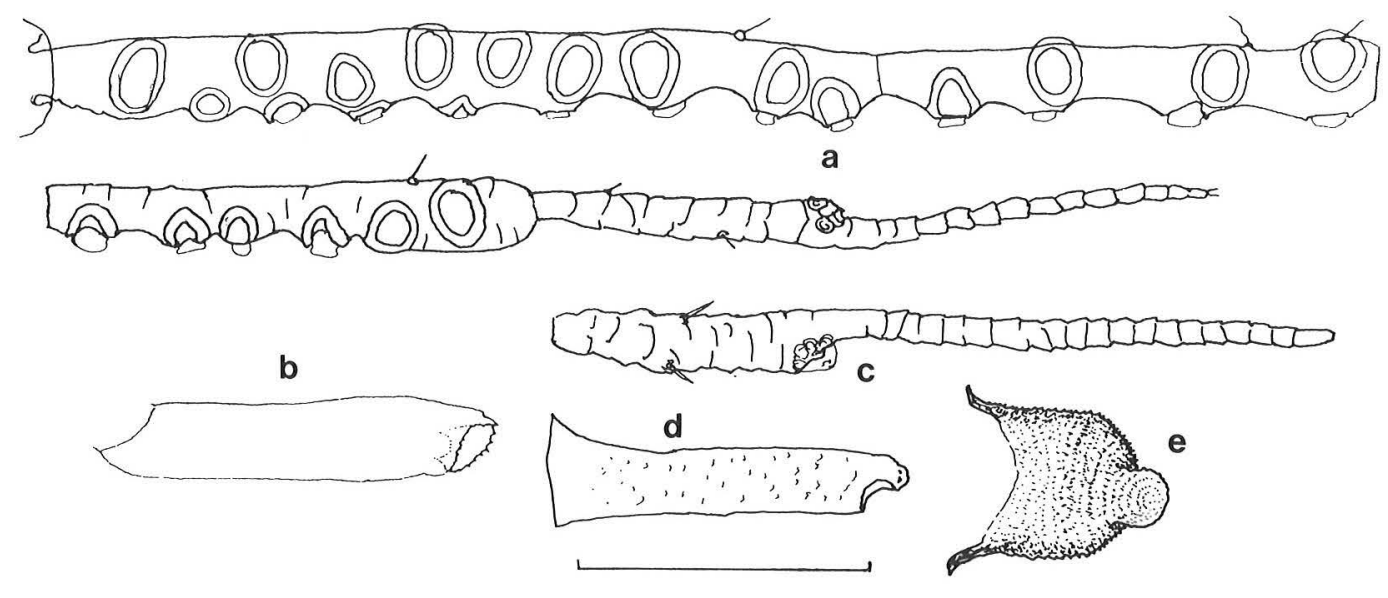

Fig. 3. Aspidaphium escherichi Börner, 1939. Alate viviparous female. a: antennal segments III-Vl; b: siphunculus (Heikinheimo 1984). Aspidaphium cuspidati Stroyan, 1955. c: antennal segment Vl; d: siphunculus; e: cauda of alate viviparous female. Scale: $0.1 \mathrm{~mm}$.

Brachycaudus (Acaudus) populi (Del Guercio, 1911)

15: 6.VII.1982 (OEH). On Silene sp.

Brachycaudus (Br.) helichrysi (Kaltenbach, 1843)

17: 6.VII.-13.X.1962 37 al, 8-13.X.1962 7 males in wnt. 3: 5.VII.1982 (OEH); 12: 1.VII.1983 (HIO). On Rumex acetosella.

Brachycaudus (Thuleaphis) rumexicolens (Patch, 1917)

17: 16.VII-24.VIII.1962 12 al in wnt. 3: 5.VII. 1982 (OEH); 12: 1.VII.1983 (HIO). On Rumex acetosella.

Brevicoryne brassicae (Linnaeus, 1758)

Reported from Åland by Vappula $(1962,1965)$. 17: 21.VII.1962 1 al in wnt.

\section{Capitophorus carduinus (Walker, 1850)}

29: 30.VI.1984 (HIO). On Carduus acanthoides (Heikinheimo 1990).
Capitophorus hippophaes (Walker, 1852)

17: 1.VII.-28.IX.1962 16 al and 28.IX.-6.X.1962 2 males in wnt.

Capitophorus horni Börner, 1931 ssp. gynoxantha Hille Ris Lambers, 1953

17: 26.VI.-8.VIII.1962 11 al and 8.X.1962 1 male in wnt.

Capitophorus similis van der Goot, 1915

17: 25.VI.-8.IX.1962 155 al and 7-10.XI.1962 2 males in wnt. 14: 6.VII.1982 (OEH); 19: 4.VII. 1982 (OEH); 21: 3.VIII.1980 (KKY). On Tussilago farfara.

Cavariella aegopodii (Scopoli, 1763)

17: 19.VI.-26.X.1962 147 al and 8.X.1962 1 male in wnt.

Cavariella archangelicae (Scopoli, 1763)

17: 22.VI.-26.IX.1962 19 al and 11.X.7.XI.1962 4 males in wnt. 6: 19.VII.1982 (HIO); 19: 19.VII.1982 (HIO); 29: 20.VII.1982 (HIO). On Angelica archangelica ssp. litoralis. 


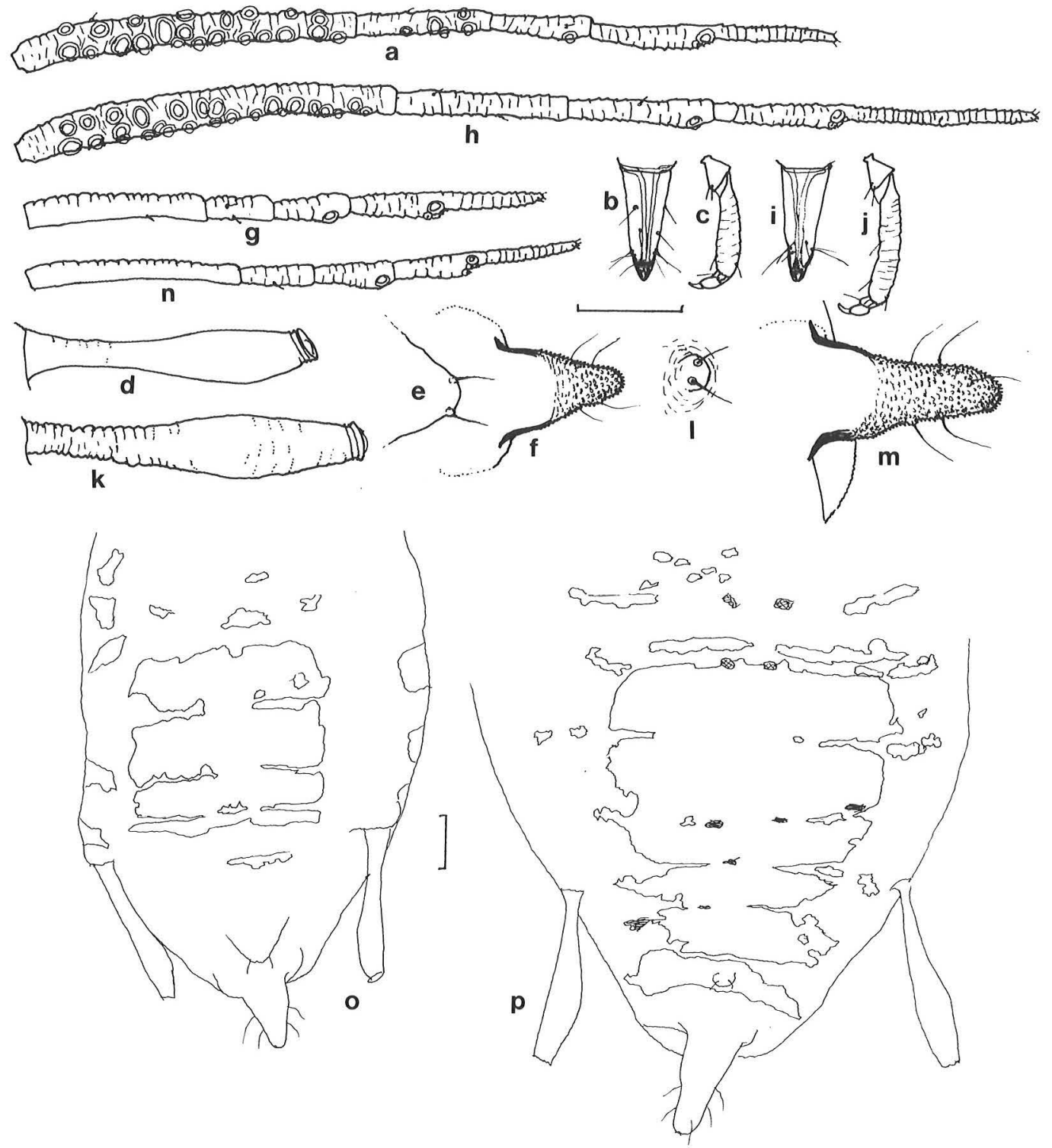

Fig. 4. Cavariella intermedia Hille Ris Lambers, 1969. a-f and o: alate viviparous female, g: apterous viviparous female. Cavariella aegopodii (Scopoli, 1763). h-m and p: alate viviparous female, $\mathrm{n}$ : apterous viviparous female. $\mathrm{a}, \mathrm{h}, \mathrm{g}$ and $\mathrm{n}$ : antennal segments III-VI; $\mathrm{b}$ and $\mathrm{i}$ : apical rostral segment; $\mathrm{c}$ and $\mathrm{j}$ : hind tarsus; $\mathrm{d}$ and $\mathrm{k}$ : right siphunculus; $e$ and l: supracaudal process; $f$ and $\mathrm{m}$ : cauda; $o$ and $\mathrm{p}$ : dark patterns on abdomen. Scale: $0.1 \mathrm{~mm}$.

**Cavariella intermedia Hille Ris Lambers, 1969 (Fig. 4)

17: 7-9.VII.1962 2 al in wnt.

The species has been also collected in Elimäki (N) 673:47, 23.VI.1986 (P. Alanko leg): 1 al and
1 apt. on Salix viminalis, and caught in Mikkeli (Sa) 684:51, 19-27.VI.1966, 6 al in wnt.

Hille Ris Lambers (1969) has indicated the differences between $C$. aegopodii and $C$. intermedia. The most striking difference is the ab- 
sence of SR on ant IV in aegopodii, whereas intermedia has 2-5 SR on ant IV. Another differences concern the ratios PT/B and Ars/Ht2, the shape of the $\mathrm{Ca}$ and the shape of the dorsal sclerotic pattern on abd. (Fig. 40, p) which are rather pale in $C$. intermedia. It differs from $C$. cicutae (Koch, 1854) (Rupais 1969 fig. 230 as $C$. rutila Mamontova, 1961) in having the length of Si more than $2 \times \mathrm{Ca}$ (Heinze 1960).

Biometric data of those 3 al mentioned above (measurements in mm): Body 1.75-2.10; ant $\mathrm{f}$ 0.838-0.986; ant III 0.350-0.414; B 0.121-0.138; PT 0.127-0.138; Si 0.290-0.335; Ca0.128-0.155; Ars $0.115-0.125$; Ht2 0.104-0.107. Length ratios: Ant f/body 0.42-0.48; Si/body 0.15-0.17; PT/B 0.98-1.05; Si/Ca 2.16-2.27; Ars/Ht2 1.101.17. Number of: $\mathrm{CH} 4-5$; SH 2-4; SR ant III 19-29, IV 2-5, V 0.

Cavariella konoi Takahashi, 1939

17: 25.VI.-11.IX.1962 5 al in wnt. 19: 4.VII.1982 (OEH), 20.VII.1982 (HIO). On Angelica archangelica ssp. litoralis.

Cavariella pastinacae (Linnaeus, 1758)

17: 26.VI.-26.VII.1962 52 al in wnt. 4: 2.VII.1984 (HIO); 7: 7.VII.1984 (HIO); 13: 4.VII.1984 (HIO); 19: 4.VII.1982 (OEH). On Salix pentandra, Heracleum sphondylium.

Cavariella theobaldi (Gillette \& Bragg, 1918)

17: 21.VI.-4.VIII.1962 12 al in wnt. 19: 1821.VII.1982 (HIO). On Salix alba.

Ceruraphis eriophori (Walker, 1848)

17: 23.VI.-9.VII.1962 21 al, 19.IX.-26.X.1962

2 sex., and 6-20.X. 4 males in wnt.

Chaetosiphon (Pentatrichopus) potentillae (Walker, 1850)

17: 30.VI.-3.VIII.1962 4 al in wnt.

Corylobium avellanae (Schrank, 1801)

1: 29.VI.1983 (HIO); 19: 18.VII.1982 (HIO). On Corypus avellana.
Cryptomyzus galeopsidis (Kaltenbach, 1843)

17: 21.VI.-20.IX.1962 159 al and 11.X.7.XI.1962 2 males in wnt. 13: 8.IX.1981 (HIO); 22: 2.VIII.1980 (KKY). On Ribes nigrum and Lamium purpureum.

Cryptomyzus ribis (Linnaeus, 1758)

Reported from Åland by Vappula $(1962,1965)$. 17: 26.VI.-26.VII.1962 13 al in wnt.

Decorosiphon corynothrix Börner, 1939

17: 18-25.VII.1962 2 al in wnt.

Diuraphis (D.) muehlei (Börner, 1950)

17: 19.VII.1962 2 al in wnt.

Diuraphis (Holcaphis) calamagrostis (Ossiannilsson, 1959)

17: 18.VII.1962 1 al in wnt.

Diuraphis (Holcaphis) frequens (Walker, 1848)

17: 18.VII.-7.VIII.1962 20 al in wnt.

Dysaphis (D.) anthrisci Börner, 1950

Vappula $(1962,1965)$ reported Dysaphis sp. on Malus from Åland. 2: 30.VI.1983 (HIO). On Malus domestica.

No other species than D. anthrisci are hitherto known from red galls on Malus in Finland, therefore, the aphid records of Dysaphis sp. on Malus mentioned by Vappula $(1962,1965)$ most probably represent this species.

Dysaphis (D.) ranunculi (Kaltenbach, 1843)

17: 20.VII.-11.X.1962 11 al in wnt.

Dysaphis (Pomaphis) plantaginea (Passerini, 1860)

17: 9-19.VII.1962 3 al, 18-20.IX.1962 3 sex., and 13.X.1962 1 male in wnt. 


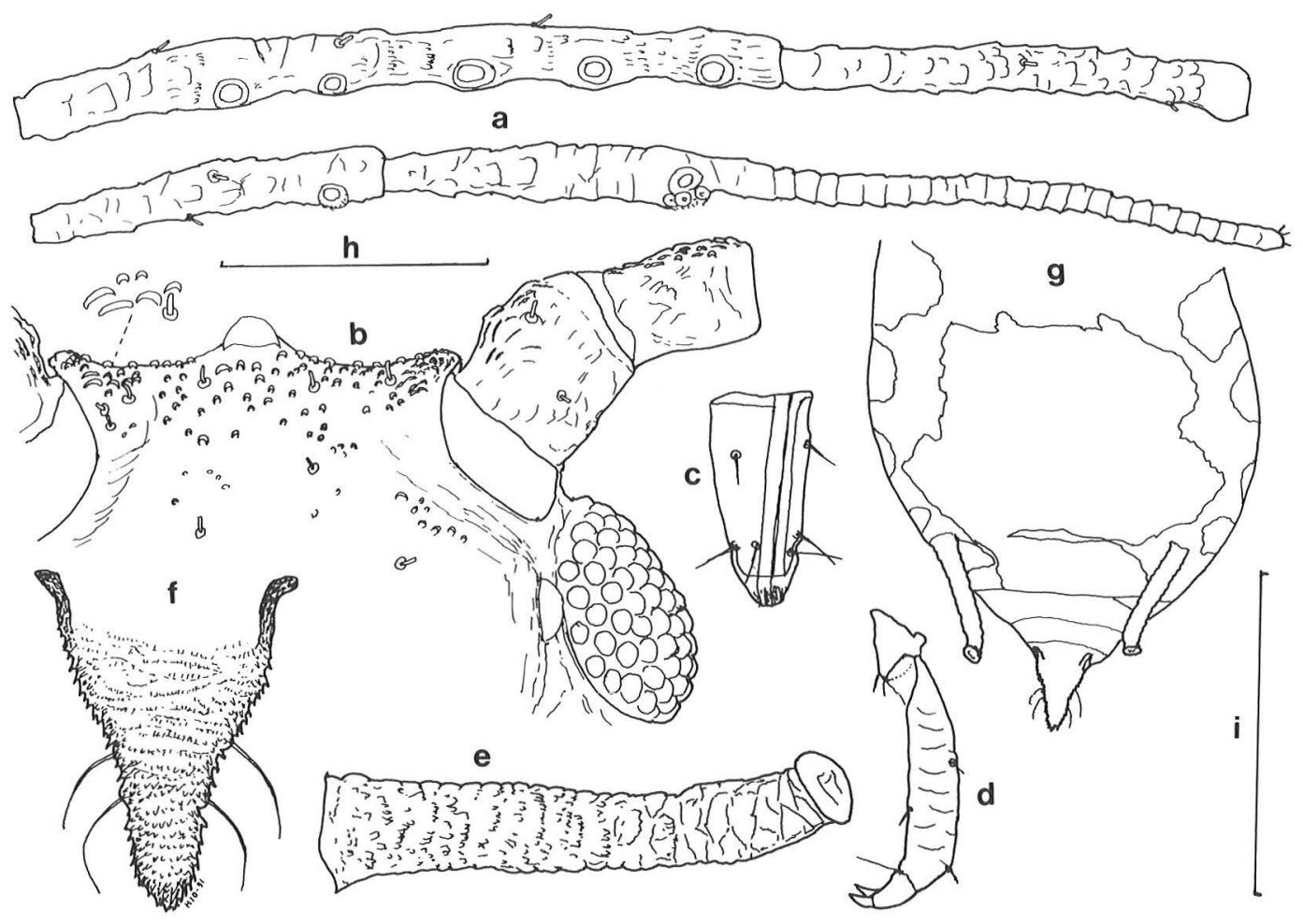

Fig. 5. Galiobium langei Börner, 1933. Alate viviparous female. a: antennal segments III-VI; b: fore-head and antennal segments I and II; c: apical rostral segment; d: hind tarsus; e: siphunculus; f: cauda; g: abdomen with dorsal sclerotic pattern. Scale i: $0.5 \mathrm{~mm}$ for $\mathrm{g}$, scale $\mathrm{h}: 0.1 \mathrm{~mm}$ for the others.

Dysaphis (Pomaphis) sorbi (Kaltenbach, 1843)

17: 27.VI.-13.X.1962 95 al and 26.X.1962 1 male in wnt. 19: 4.VII.1982 (OEH); 28: 30.VI.1984 (HIO). On Sorbus aucuparia.

*Galiobium langei (Börner, 1933) (Fig. 5)

17: 10. and 19.VII.1962 2 al in wnt.

The most striking characters of the small al are the large roundish sclerotic dorsal pattern on abd, the squamose black sipunculi bent outwards on their distal part, the shape of the fore head with numerous small wart-like elevations, and the rugose ant III with few SR (Fig. 5).

Biometric data of two al (measurements in mm): Body 1.40, 1.42; ant f 0.926, 0.944; ant III
0.285, IV 0.175, 0.167, V 0.131, 0.150; B 0.12; PT 0.215, 0.222; Si 0.195, 0.200; Ca 0.115, 0.136; Ars 0.080, 0.085; Ht2 0.085, 0.087; HL ant III 7, 8; HL fore head 6, 7; HL abd III 7, VIII 8. Length ratios: Ant f/body 0.66; Si/body 0.14; hind tibia/ body 0.45 ; PT/B 1.79, 1.85; Si/Ca 1.50, 1.74; Ars/Ht2 0.92, 1.00. Number of: CH 4; SH 2; SR ant III 5-6, IV 0-1, V 0.

Hyadaphis foeniculi (Passerini, 1860)

17: 17.VIII.1962 1 al in wnt.

Hyadaphis passerini (del Guercio, 1911)

17: 17.VIII.1962 1 al in wnt. 


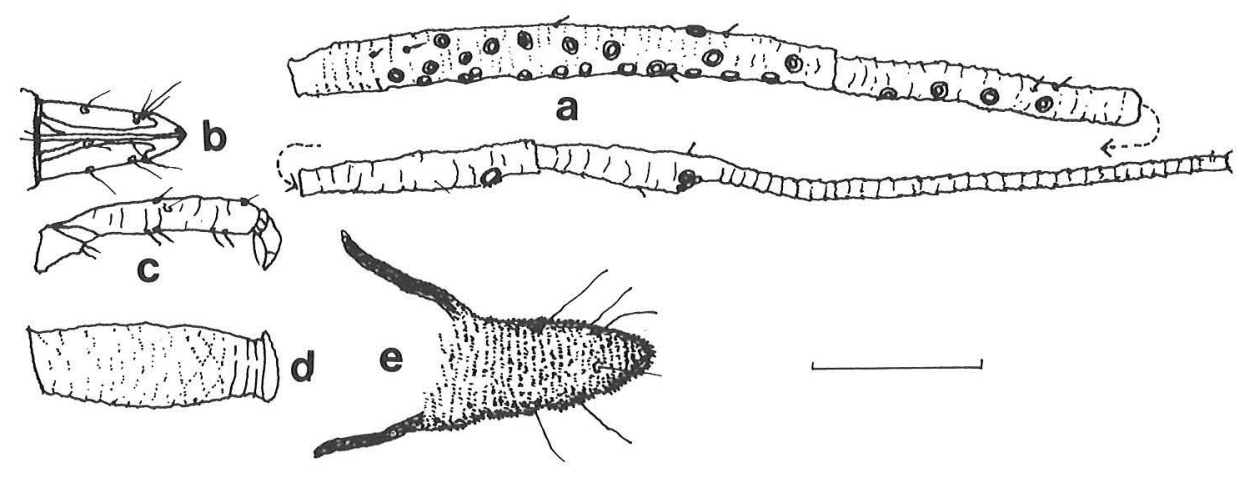

Fig. 6. Hyadaphis tataricae (Ajzenberg, 1935). Alate viviparous female. a: antennal segments III-VI; b: apical rostral segment; c: hind tarsus; d: siphunculus; e: cauda. Scale: $0.1 \mathrm{~mm}$.

*Hyadaphis tataricae (Aizenberg, 1935) (Fig. 6)

17: 14.VII.-27.VIII.1962 16 al in wnt.

Two al have also been catched with sweep net in Parikkala (Kl) 683:62, 30.VI.1990 (HIO).

Shaposhnikov (1964) keyed the species, Müller \& Buhr (1965) and Voegtlin (1982) gave detailed descriptions, and Rupais (1969) provided detailed illustrations. The barrel-shaped $\mathrm{Si}, 3 \mathrm{x}$ their diameter in length, occur in Brevicoryne brassicae, Hayhurstia atriplicis and Hyadaphis tataricae, but only in the last mentioned does ant IV and sometimes also ant V have SR. In the descriptions the number of SR vary as follows: ant III 17-23, IV 4-9, V 0-2 (Voegtlin 1982); ant III 30-34, IV 6-11, V 0-1 (Müller \& Buhr 1965). In the al from Finland the variation is as follows: ant III 14-32, IV 1-9, V 0-2.

Biometric data of 7 al females (measurements in $\mathrm{mm}$ ): body $1.23-1.83$; ant $\mathrm{f} 0.794-$ 1.052; ant III 0.270-0.330, IV 0.102-0.180, V 0.100-0.142; B 0.90-0.117; PT 0.228-0.310; Si 0.100-0.145; Ca 0.152-0.188; Ars 0.076-0.090; Ht2 0.105-0.120. Length ratios: Ant f/body 0.560.65; PT/B 2.32-3.30; PT/ant III 0.83-0.97; Ca/ Si 1.30-1.52; Si/body 0.066-0.079; Ars/Ht2 0.700.79 ; HL ant III/BD ant III 0.50. Number of: $\mathrm{CH}$ 6; SH 2.

Hyalopteroides humilis (Walker, 1852)

17: 9-22.VII.1962 2 al in wnt.
Hyalopterus pruni (Geoffroy, 1762)

Reported from Åland by Vappula $(1962,1965)$. 17: 21.VII.-16.X.1962 34 al and 3.X.1962 1 male in wnt. 2: 30.VI.1983 (HIO); 6: 19.VII.1982 (HIO); 9: 21.VII.1982 (HIO); 11: 4.VII.1984 (HIO); 19: 3.VIII.1980 (KKY); 22: 2.VIII.1980 (KKY). On Prunus domestica and Phragmites communis.

Hydaphias mosana Hille Ris Lambers, 1956

17: 30.VII.1962 2 al in wnt.

Hyperomyzus (H.)lactucae (Linnaeus, 1758)

17: 28.VI.-18.VIII.1962 83 al in wnt. 5: 19.VII.1982 (HIO); 19: 3.VIII.1980 (KKY). On Ribes nigrum and Sonchus arvensis.

Hyperomyzus (H.) pallidus Hille Ris Lambers, 1935

17: 19.VI.-10.VIII.1962 28 al in wnt. 6: 19.VII.1982 (HIO). On Sonchus arvensis.

Hyperomyzus (Hyperomyzella) rhinanthi (Schouteden, 1903)

17: 22.VI.-6.X.1962 61 al in wnt. 3: 19. VII.1982 (HIO); 21: 6.VII.1984 (HIO). On Rhinanthus major. 
Hyperomyzus (Neonasonovia) zirnitsi Hille Ris Lambers, 1952

17: 22.VI.-2.VIII.1962 33 al in wnt. 10: 21.VII. 1982 (HIO). On Ribes alpinum.

Liosomaphis berberidis (Kaltenbach, 1843)

19: 6.VII.1982 (OEH), 18-21.VII.1982 (HIO). On Berberis thunbergi.

Longicaudus trirhodus (Walker, 1849)

2: 27.VI.1952 (N.A. Vappula leg.) (Vappula 1962, 1965, Heikinheimo 1963). On Rosa sp.

Macrosiphoniella artemisiae (Boyer de Fonscolombe, 1841)

19: 19-21.VII.1982 (HIO). On Artemisia vulgaris.

Macrosiphoniella millefolii (DeGeer, 1773)

17: 21.VII.-2.VIII.1962 7 al in wnt. 3: 5.VII.1982 (OEH); 8: 6.VII.1982 (OEH); 19: 4.VII.1982 (OEH); 29: 20.VII.1982 (HIO). On Achillea millefolium and Tanacetum vulgare.

Macrosiphoniella sejuncta (Walker, 1848)

17: 24.VII.-10.VIII.1962 4 al in wnt. 21: 6.VII. 1984 (HIO).

Macrosiphoniella tanacetaria (Kaltenbach, 1843)

17: 18-26.VII.1962 2 al in wnt. 13: 4.VII.1984 (HIO); 24: 8.VII.1984 (HIO). On Tanacetum vulgare.

Macrosiphoniella tapuskae (Hottes \& Frison, 1931)

17: 26-31.VII.1962 4 al in wnt.

Macrosiphoniella usquertensis Hille Ris Lambers, 1935

17: 25.VI.1962 1 al in wnt.
Macrosiphum cholodkovskyi (Mordvilko, 1909)

3: 19.VII.1982 (HIO); 7: 7.VII.1984 (HIO); 29: 20.VII.1982 (HIO). On Filipendula ulmaria.

Macrosiphum gei (Koch, 1855)

17: 24.VI.-24.VII.1962 12 al in wnt.

Macrosiphum rosae (Linnaeus, 1758)

17: 3-31.VII.1962 2 al in wnt. 3: 5.VII.1982 (OEH); 5: 4.VIII.1980 (KKY); 17: 6.VII.1984 (HIO); 19: 6.VII.1982 (OEH); 22: 2.VIII.1980 (KKY); 29: 20.VII.1982 (HIO). On Rosa sp.

Megoura viciae Buckton, 1876

17: 20.VII.-14.VIII.1962 2 al in wnt. 19: 19.VII.1982 (HIO).

*Melanaphis luzulella (Hille Ris Lambers, 1939) (Fig. 7)

17: 27.VI.-24.VII.1962 2 al in wnt.

The species has also been caught in Rovaniemi rural mun. $(O b N)$ 738:45 15.VII.1965 in wnt.

The long sense peg on the fore and middle tarsi, marginal tubercles on abd VI, and 5-segmented antennae are distinct diagnostic characters of the species (Stroyan 1984, Heie 1986).

Biometric data of two al females (measurements in mm): Body 1.47, 1.73; ant f 0.90, 0.92; ant III 0.40, 0.41; B 0.14; PT 0.25, 0.27; Si 0.18; Ca 0.12; Ars 0.082; Ht2 0.084. Length ratios: Ant f/body 0.52,0.63; Si/body 0.10, 0.12; PT/B 2.27, 2.86; Si/Ca 1.46, 1.50; Ars/Ht2 0.96, 0.99; HL ant III/BD ant III 0.88, 1.00. Number of: CH 5, 6; SH 2; SR ant III 15, 16, IV 2, 3, V 0.

Metopeurum fuscoviride Stroyan, 1950

4: 2.VII.1984 (HIO); 13: 4.VII.1984 (HIO); 15: 6.VII.1982 (OEH). On Tanacetum vulgare.

Metopolophium dirhodum (Walker, 1849)

17: 9.VII.-11.X.1962 10 al and 11-26.X.1962 3 males in wnt. 


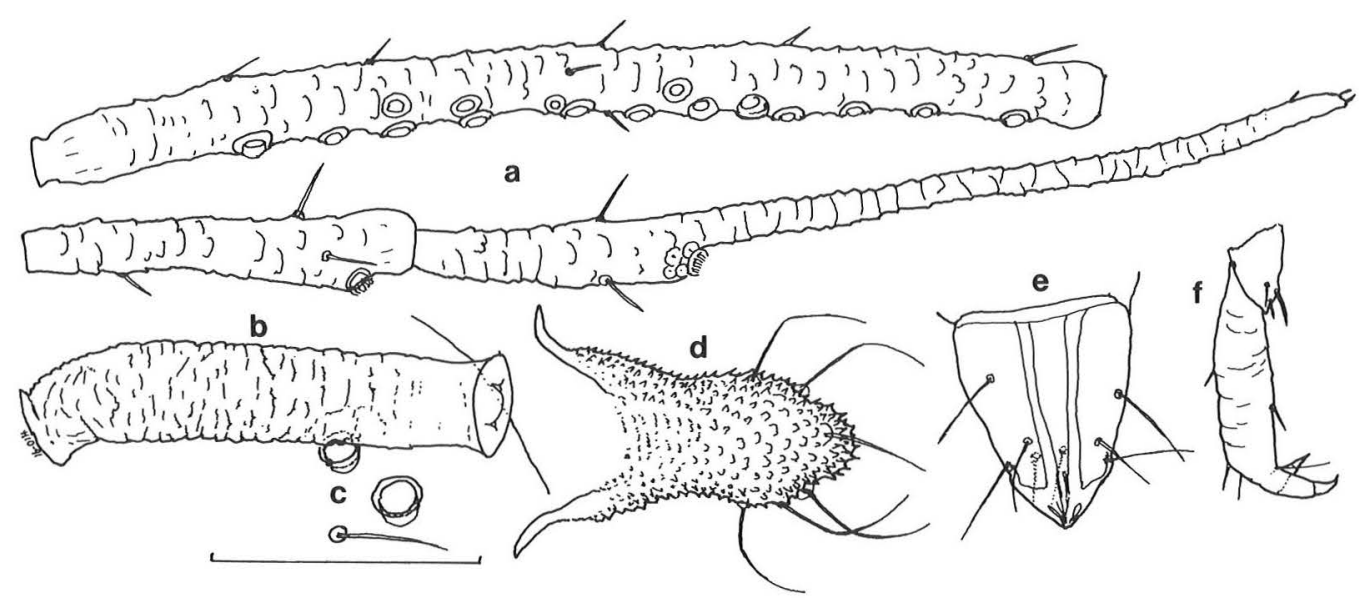

Fig. 7. Melanaphis luzulella Hille Ris Lambers, 1939. Alate viviparous female. a: antennal segments III-V. b: right siphunculus; c: stigma, marginal tubercle and a hair on the right side of abdominal segment VIl; d: cauda; e: apical rostral segment; f: hind tarsus. Scale: $0.1 \mathrm{~mm}$.

Metopolophium festucae (Theobald, 1917)

17: 19.VI.-7.VIII.1962 11 al in wnt.

Metopolophium tenerum Hille Ris Lambers, 1947

17: 13.X.1962 1 male in wnt.

Microlophium carnosum (Buckton, 1876)

17: 6.VII.-8.VIII.1962 18 al in wnt. 7: 7.VII.1984 (HIO). On Urtica dioica.

Myzaphis rosarum (Kaltenbach, 1843)

17: 6.VII.1984 (HIO). On Rosa sp.

Myzosiphon staphyleae (Koch, 1854)

17: 10.VII.-1.X.1962 4 al in wnt.

Myzus borealis Ossiannilsson, 1959

17: 14.VIII.1962 1 al in wnt.

Myzus cerasi (Fabricius, 1775)

Reported in 1917 from Åland (Linnaniemi 1935, Vappula 1962, 1965). 17: 4.VII.-20.X.1962 16 al and 11.X.-10.XI.1962 6 males in wnt. 9: 21.VII.1982 (HIO); 19: 5.VII.1982 (OEH), 20.VII.1982 (HIO). On Prunus cerasus and P. avium.

Nasonovia pilosellae (Börner, 1933)

17: 11.VII.1962 1 al in wnt. 5: 1.VII.1983 (HIO); 6: 19.VII.1982 (HIO); 11: 1.VII.1983 (HIO). On Hieracium sp. and $H$. aurantiacum.

Nasonovia ribisnigri (Mosley, 1841)

17: 1.VII.-22.VIII.1962 45 al and 6.X.1962 1 male in wnt. 3: 19.VII.1982 (HIO).

Neoamphorophora ledi (Wahlgren, 1932)

Jomala, Karrböle 1940-45 (Krogerus 1960).

Ovatus crataegarius (Walker, 1850)

17: 9-23.VII.1962 2 al in wnt.

Phorodon humuli (Schrank, 1801)

Finström, Örnäs 1917 (Linnaniemi 1935), Vappula (1962, 1965). 17: 5.VII.-4.VIII.1962 11 al and 18.IX.1962 2 males in wnt. 

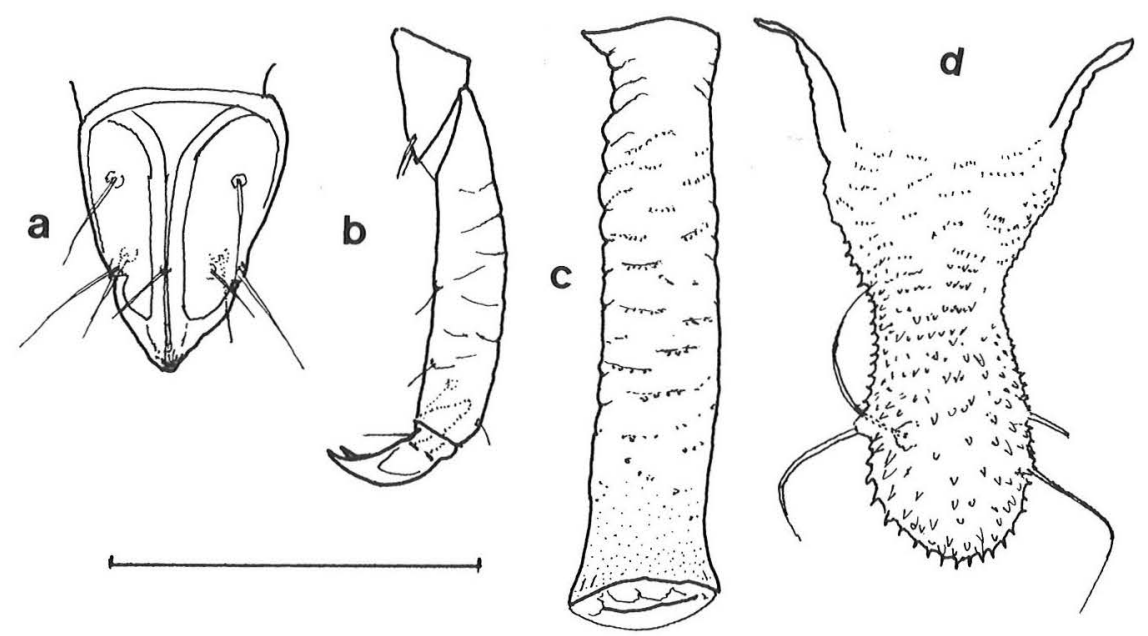

Fig. 8. Schizaphis borealis Tambs-Lyche, 1959. Alate viviparous female. a: apical rostral segment; b: hind tarsus; c: siphunculus; d: cauda. Scale: $0.1 \mathrm{~mm}$.

Pseudorhopalosiphoninus calthae (Koch, 1854)

17: 9.VII.1962 1 al in wnt.

Rhopalomyzus lonicerae (von Siebold, 1839)

19: 18-21.VII.1982 (HIO). On Lonicera tatarica.

Rhopalosiphoninus ribesinus (van der Goot, 1912)

17: 7-26.VII.1962 2 al in wnt.

Rhopalosiphum insertum (Walker, 1849)

17: 28.VI.-28.X.1962 481 al and 3.X.-2.XI.1962 42 males in wnt. 1: 27.V.1982 (HIO); 23: 26.IX.1981 (HIO). On Malus domestica and Sorbus aucuparia.

Rhopalosiphum maidis (Fitch, 1856)

17: 12.VIII.1962 5 al in wnt.

Rhopalosiphum padi (Linnaeus, 1758)

17: 16.VI.-28.X.1962 805 al and 11.IX.28.X.1962 38 males in wnt. 3: 19.VII.1982 (HIO); 5: 29.VI.1983 (HIO); 6: 19.VII.1982 (HIO); 9:
6.VII.1982 (OEH); 15: 6.VII.1982 (OEH); 17: 28.V.1982 (HIO); 19: 19.VII.1982 (HIO); 21: 6.VII.1984 (HIO); 29: 20.VII.1982 (HIO); 30: 20.VII.1982 (HIO). On Carex leporina, Juncus gerardi, J. lampocarpus, Phragmites communis, Scirpus maritimus.

*Schizaphis borealis Tambs-Lyche, 1959 (Fig. 8)

17: 3-19.VII.1962 6 al in wnt.

The species has also been found in the following other localities in Finland: Helsinki rural municipality $(N)$ 668:39 1.VIII.1963 in wnt, Mikkeli ( $\mathrm{Sa}$ ) 684:51 21.VI.-30.VII.1967 in wnt, Vimpeli $(\mathrm{Om}) 700: 34$ 5.VII.1985 on grass, and Rovaniemi rural mun. $(O b N)$ 738: 45 20.VII.1962, 29-30.VII.1963, and 24.VII.1967 in wnt.

Schizaphis agrostis Hille Ris Lambers, 1947 and Sch. borealis are very similar species with pale siphunculi. In the latter $1 / 4$ of the distal part of siphunculi is slightly dusky, in the former not. The length ratio $\mathrm{Si} / \mathrm{Ca}$ is $1.00-1.20$ in borealis, whereas 1.25-1.50 in agrostis (Tambs-Lyche 1959, Heie, 1986).

Biometric data of the al captured in Aland (measurements in $\mathrm{mm}$ ): B 0.090-0.109; PT 0.305-0.365; Si 0.160-0.180; Ca 0.144-0.169; 


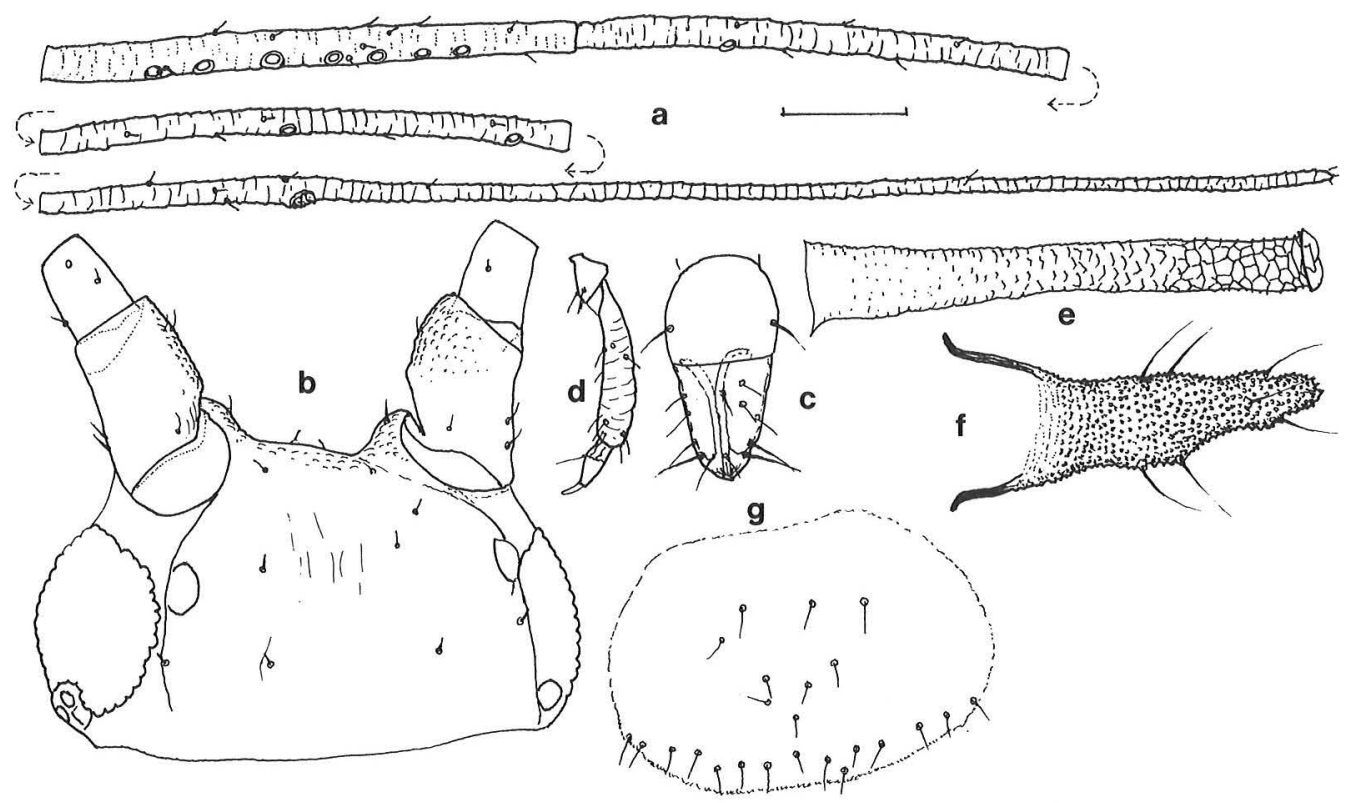

Fig. 9. Sitobion equiseti Holman, 1961. Alate viviparous female. a: antennal segments III-VI; b: head and antennal segments I and II; c: apical rostral segment; d: hind tarsus; e: siphunculus; f: cauda; g: subgenital plate. Scale: 0.1 $\mathrm{mm}$.

Ars 0.067-0.076; Ht2 0.080-0.103. Length ratios: PT/B 3.17-3.83; Si/Ca 1.00-1.19; Ars/Ht2 0.23-0.88. Number of: SR ant III 1-5; MT 0

Sitobion (S.) avenae (Fabricius, 1775)

Reported from Åland by Vappula $(1962,1965)$. 17: 21.VI.-26.X.1962 98 al and 11.X.1962 2 males in wnt. 2: 28.VI.1983 (HIO); 3: 19 .VII.1982 (HIO); 5: 29.VI.1983 (HIO); 6: 19.VII.1982 (HIO); 17: 30.VI.1983 (HIO); 21: 4. VIII.1980 (KKY); 29: 20.VII.1982 (HIO); 30: 20.VII.1982 (HIO). On Carex leporina and Scirpus maritimus.

\section{*Sitobion (S.) equiseti Holman, 1961 (Fig. 9)}

17: 11.VIII.1962 1 al in wnt.

Another al has been captured in Laukaa $(\mathrm{Tb})$ 690:45 21.VI.1989 (HIO).

Biometric data of the two al specimens (measurements in mm): Body 2.66, 2,23; ant $\mathrm{f}$ 2.38 (in the another both are broken); ant III $0.468,0.580$; B 0.217; PT 0.850; hind tibia 1.43;
Si 0.42,0.54; Ca 0.30; Ars 0.100, 0.105; Ht2 0.123,0.133; BD ant III 30; HL ant III 13, 15; HL abd III 12,17, abd VIII 20, 52. Length ratios: Ant f/body 0.87 ; Si/body $0.16,0.24$; hind tibia/body 0.53, 0.63; PT/B 3.86; Si/Ca 1.38, 1.80; Ars/Ht2 $0.79,0.81$; HL ant III/BD ant III $0.43,0.50$. Number of: CH 7; SH 6; hairs on abd VIII 4, 5; SR ant III 4-7, IV 0-1, V 1.

In the specimens from Finland the cauda is relatively longer and more slender, and $\mathrm{Ht} 2$ is longer than described by Holman (1961).

Sitobion (S.) fragariae (Walker, 1848)

17: 30.VI.-18.VII.1962 3 al and 5.XI.1962 1 male in wnt. 29: 20.VII.1982 (HIO). On Carex leporina.

Sitobion (Metobion) graminearum (Mordvilko, 1919)

17: 8.VII.1962 1 al in wnt.

The diagnostic characters of the al specimen fit well with those represented earlier (Heikinheimo 1990). 
Biometric data (measurements in mm): Body 3.50; ant f 3.86; ant III 0.94; B0.19; PT 1.29; Si 0.59; Ca 0.41. Length ratios: ant f/body 1.10 ; PT/B 6.79; PT/ant III 1.38; Si/body 0.17; Si/Ca 1.43; Ars/Ht2 0.57. Number of: $\mathrm{CH} 11$; $\mathrm{SH} 2$; SR ant III 14, 16, IV 0, V 0.

Subacyrthosiphon cryptobium Hille Ris Lambers, 1947

17: 15.VII.1962 1 al in wnt.

Trichosiphonaphis corticis (Aizenberg, 1935)

6: 19.VII.1982 (HIO); 19: 3.VIII.1980 (KKY)

(Heikinheimo 1984). On Lonicera xylosteum.

Tubaphis ranunculina (Walker, 1852)

17: 11-22.VII.1962 5 al and 28.IX.1962 1 male in wnt.

Uroleucon (U.) achilleae (Koch, 1855)

19: 14.VI.1960 (Thuneberg 1962). 17: 28.VI.12. VIII.1962 31 al in wnt.

Uroleucon (U.) cichorii (Koch, 1855) ssp. grossum (Hille Ris Lambers, 1939)

19: 21.VII.1982 (HIO). On Hieracium umbellatum.

Uroleucon (U.) cirsii (Linnaeus, 1758)

8: 6.VII.1982 (OEH). On Cirsium arvense.

Uroleucon (Uromelan) jaceae (Linnaeus, 1758)

17: 2-30.VII.1962 4 al in wnt. 3: 19.VII.1982, 5.VII.1984 (HIO); 6: 1.VII.1984 (HIO). On Centaurea jacea.

Uroleucon (Uromelan) solidaginis (Fabricius, 1781)

9: 21.VII.1982 (HIO). On Solidago virgaurea.

Uroleucon (Uromelan) taraxaci (Kaltenbach, 1843)

17: 8.VII.1962 1 al in wnt.
Wahlgreniella vaccinii (Theobald, 1924)

17: 9-15.VII.1962 2 al in wnt.

LACHNIDAE - LACHNINAE

Lachnus roboris (Linnaeus, 1758)

Reported from Åland by Vappula $(1962,1965)$.1: 29.VI.1983 (HIO); 4: 4.VIII.1980 (KKY); 11: 1.VII.1983, 4.VII.1984 (HIO); 21: 6.VIII.1980 (KKY); 24: 2.V.1965 (I. Jalas leg.); 30: Nordman (1943). On Quercus robur.

Maculolachnus submacula (Walker, 1848)

17: 13.VIII.1962 1 al in wnt. 20: 14.VI.1960 (Thuneberg 1962), 5.VIII.1980 (KKY), 8.IX.1981 (HIO). On Rosa rugosa, Rosa sp.

LACHNIDAE - CinARINAE

Cinara costata (Zetterstedt, 1828)

4: 19.VII.1982 (HIO). On Picea abies.

Cinara diversiseta Börner, 1952

11: 1.VII.1983 (HIO); 26: 21.VII.1982 (HIO). On Pinus sylvestris.

Cinara juniperi (DeGeer, 1773)

17: 8-9.VII.1962 2 al in wnt; 2: 28.VI.1983 (HIO); 21: 6.VII.1984 (HIO). On Juniperus communis.

Cinara nuda (Mordvilko, 1895)

13: 4.VII.1984 (HIO); 29: 30.VI.1984 (HIO). On Pinus sylvestris.

Cinara piceae (Panzer, 1801)

17: 14.VII.1962 1 al in wnt. 10: 29.VI.1984 (HIO); 18: 2.VII.1984 (M. Koponen leg.); 19: 29.VI.1984 (HIO); 22: 8.VII.1984 (V. Vikberg leg.). 
Cinara pilicornis (Hartig, 1841)

17: 15.VII.1962 1 al in wnt. 4: 19.VII.1982 (HIO).

On Picea abies.

Cinara pilosa (Zetterstedt, 1838)

17: 16.VII.1962 1 al in wnt. 26: 21.VII.1982 (HIO); 29: 30.VI.1984 (HIO). On Pinus sylvestris.

Cinara pinea (Mordvilko, 1895)

3: 19.VII.1982 (HIO); 4: 2.VII.1984 (HIO); 9: 21.VII.1982 (HIO); 10: 6.VII.1982 (OEH); 12: 1.VII.1983 (HIO); 13: 4.VII.1984 (HIO); 18: 4.VIII.1980 (KKY); 26: 20-21.VII.1982 (HIO); 29: 30.VI.1984 (HIO). On Pinus sylvestris.

\section{Cinara pini (Linnaeus, 1758)}

17: 14.VII.1962 1 al in wnt. 11: 1.VII.1983 (HIO); 17: 29.VI.1984 (HIO); 26: 20.VII.1982 (HIO); 29: 20.VII.1982, 30.VI.1984 (HIO). On Pinus sylvestris.

Cinara pinihabitans (Mordvilko, 1895)

17: 5-18.VII.1962 4 al in wnt. 21-24: 17.VI.1966 (F. Ossiannilsson leg.) (Eastop 1972).

Cinara pruinosa (Hartig, 1841)

17: 29.VI.1984 (HIO). On Picea abies.

Cinara viridescens (Cholodkovsky, 1898)

4: 19.VII.1982 (HIO); 17: 29.VI.1984 (HIO); 22: 2.VIII.1980 (KKY) (Heikinheimo 1984). On Picea abies.

Eulachnus agilis (Kaltenbach, 1843)

17: 5-25.VII.1962 18 al in wnt.

Schizolachnus pineti (Fabricius, 1781)

17: 18.VII.1962 1 al in wnt. 3: 19.VII.1982 (HIO); 4: 2.VII.1984 (HIO); 11: 1.VII.1983 (HIO); 26: 20.VII.1982 (HIO); 29: 30.VI.1984 (HIO). On Pinus sylvestris.
Lachnidae - Traminae

Protrama ranunculi (Del Guercio)

17: 7.VII.-24.VIII.1962 4 al in wnt. 4: 2.VII.1984 (HIO).

Trama troglodytes von Heyden, 1837

17: 25.VII.1962 1 al in wnt.

\section{Discussion}

Knowledge about the aphid species and subspecies of the biological province Åland can be interpreted as fairly good when we compare its species number, 200 , to respective numbers of some other biological provinces nearby in Finland: Regio aboensis $(A b)$ 159, Nylandia $(N)$ 272, Tavastia australis $(T a)$ 169. In Sweden, in other biological provinces than Upland (355) and Skåne (366), less than 200 aphid species have been found (Ossiannilsson 1969b).

With regard to the distribution of individual aphid species, one can see that most of the species found in Åland have an extensive distribution in Europe. A large proportion of the other species are rare or their distribution area is so poorly known that it is not possible to define them with reasonable precision. However, some faunal elements can be distinguished to differentiate species:

1. Eastern species: These are absent from regions extending westward from the Gulf of Bothnia and in Western Europe: Hyadaphis tataricae.

2. Southern species:

a. in Finland found only in Åland: Aphis euphorbiae, A. mammulata, A. sanguisorbae, A. sarothamni, Galiobium langei.

b. Found in Finland south of $61^{\circ} \mathrm{N}$ only: Phyllaphis fagi, Anuraphis farfarae, $\mathrm{Ca}$ pitophorus carduinus, Corylobium avellanae, Dysaphis plantaginea, Lachnus roboris.

3. Boreal species: Endemic in the Fennoscandian area, until now not found elsewhere: Chaitophorus nigricantis, Subsaltusaphis aquatilis, Diuraphis calamagrostis, Schizaphis borealis. 
Knowledge about the distribution of aphid species is continuously growing. The picture of the distribution area of different species is changing and will gradually become sharper, but erroneous conclusions are also to be expected concerning the distribution area of individual species. An example of this is Trichosiphonaphis corticis, which was regarded in the past as a species carried by the wind to North Europe (Heie 1980), but has since been discovered on its host plant in Åland and elsewhere in Southern Finland (Heikinheimo 1984).

Acknowledgements. Special thanks are due to Professor Dr. Ole E. Heie for providing the information on the aphid material collected by him in Aland, and other persons who enriched the knowledge of the aphid fauna of Åland with their aphid samples. The author wishes further to express his warmest thanks to Professor Heie for checking some aphid species. Thanks are also due to Dr. Timothy Carter for checking the language.

\section{References}

Brown, P. A. 1989: Keys to alate Aphis (Homoptera) of Northern Europe. - Brit. Mus. Occ. Papers Syst. Entomol. 5:1-29.

Eastop, V. F. 1972: A taxonomic review of the species of Cinara Curtis occurring in Britain (Hemiptera: Aphididae). - Bull. Brit. Mus. (Nat. Hist.) Entomol. 27:103-186.

Heie, O. E. 1973: Additions to a list of Danish anhids (Hom., Aphidoidea) [In Danish with English summary] — Entomol. Medd. 41:177-187.

- 1980: The Aphidoidea of Fennoscandia and Denmark I. - Fauna Entomol. Scand. 9. Scandinavian Science Press, Vinderup, Denmark. 236 pp.

- 1986: The Aphidoidea of Fennoscandia and Denmark III. - Fauna Entomol. Scand. 17. E.J. Brill, Leiden, Copenhagen. 314 pp.

Heikinheimo, O. 1963: Für die Finnische fauna neue Blattläuse (Hom., Aphidoidea) II. - Ann. Entomol. Fennici 29:184-190.

- 1984: The aphid fauna of Finland: additions, comments and descriptions of new morphs. - Notulae Entomol. 64:33-49.

- 1990: Aphid species and morphs new to the fauna of Finland (Homoptera, Aphididae, Macrosiphini). Entomol. Fennica 1:65-98.

Heikinheimo, O. \& Raatikainen, M. 1971: The recording of localities of biological finds in Finland. - Ann. Entomol. Fennici 37, 1a:1-27.

- 1981: Grid references and names of localities in the recording of biological finds in Finland. - Notulae Entomol. 61:133-154.
Heinze, K. 1960-61: Systematik der mitteleuropäischen Myzinae mit besonderer Berïcksichtigung der im Deutschen Entomologischen Institut befindlichen Sammlung Carl Börner. — Beitr. Entomol. 10:744842, 11:24-96.

Hille Ris Lambers, D. 1947: Contributions to a monograph of the Aphididae of Europe III. - Temminckia 7. Leiden: 179-320.

- 1969: Four species of Cavariella Del Guercio, 1911. - Mem. Soc. Entomol. Italiana 48:285-299.

Hintikka, T. J. 1913: Pemphiginae-kirvoista meillä [In Finnish]. - Luonnon Ystävä 17:61-68.

Holman, J. 1961: Description of two new aphid species (Sitobion equiseti sp. n. and Linosiphon asperulophagus sp. n.) from Czechoslovakia (Homoptera, Aphididae). - Acta Soc. Entomol. Czechoslov. 58:324-332.

Julin, E. 1959: The distribution of the spruce gall aphids Sacchiphantes abietis L. and Adelges laricis Vall. in Sweden (Hem. Aphid.). — Opusc. Entomol. 24:167175.

Kanervo, V. 1960: Mass appearance by certain pests in Finland in 1959. (In Finnish with English summary) — Maatalous ja Koetoiminta 14:193-207.

Koch, C. L. 1854: Die Pflanzenläuse, Aphiden, getreu nach dem Leben abgebildet und beschrieben. - Lotzbeck, Nürnberg. 335 pp.

Krogerus, H. 1960: Ökologische Studien über die nordische Moorarthropoden. - Comm. Biol. 21(3):1-238.

Linnaniemi, W. M. 1935: Bericht über das Auftreten der Pflanzenschädlinge in Finnland in den Jahren 19171923. (In Finnish with German summary) - Valtion Maatalouskoetoiminnan Julkaisuja 68:1-150.

Miyazaki, M. 1987: Morphology of aphids. In: Minks, A. K. \& Harrewijn, P. (eds.) Aphids, their biology, natural enemies and control. 2A:1-25. - Elsewier, Amsterdam.

Müller, F. P. \& Buhr, H. J. 1965: Hyadaphis tataricae (Ajzenberg) ein neuer Schädling in Mitteleuropa an Lonicera tatarica L. und einigen anderen LoniceraZiersträuchern. - Anz. Schädlingsk. 38:69-72.

Nordman, A. 1943: Till kännedomen om fjärilsfaunan i ett lundområde i det centrala skärgårdshavet i SW-Finland (Föglö-Bänö). - Memoranda Soc. Fauna Flora Fennica 18:127-164.

Ossiannilsson, F. 1962: Hemipterfynd i Norge 1960. Norsk Entomol. Tidskr. 12:56-62.

- 1969a: Notes of some Swedish aphids (Hem. Aphidoidea). - Opusc. Entomol. 34:28-34.

- 1969b: Catalogus insectorum Sueciae. Homoptera: Aphidoidea. - Opusc. Entomol. 34:35-72.

Prior, R. N. B. 1971: Some notes on new or uncommon aphids recently found in Britain. - Zool. J. Linn. Soc. 50:397-430.

Rupais, A. A. 1969: Atlas of the Baltic dendrophilous plantlice. (In Russian with English summary) — Riga. $364 \mathrm{pp}$.

Shaposhnikov, G. K. 1964: Suborder Aphidinea — Plant lice. - In: Bey-Bienko, G. Y. (ed.), Keys to the in- 
sects of the European part of the U.S.S.R.: 616-799. [In Russian, English translation]. Jerusalem.

Stroyan, H. L. G. 1963: Notes on the species of Aspidaphium Börner, 1939. — Beitr. Entomol. 13:81-88.

- 1984: Aphids - Pterocommatinae and Aphidinae (Aphidini) Homoptera, Aphididae. - Handb. Ident. British Insects 2:1-232.

Tambs-Lyche, H. 1959: A new species of Schizaphis Börner (Hom., Aphid.) attacking Phleum pratense in Norway. — Norsk Entomol. Tidskr. 11:88-93.

Thuneberg, E. 1962: Beiträge zur Kenntnis der finnischen Blatt- und Schildläuse (Hom, Aphidoidea et Coccoidea) sowie deren Parasiten I. - Ann. Entomol. Fennici 26:97-99.

Vappula, N. A. 1962: Suomen viljelykasvien tuhoeläinlajisto. - Ann. Agric. Fenniae 1, Suppl. 1(1):1-275.

- 1965: Pests of cultivated plants in Finland. - Acta Entomol. Fennica 19:1-239.

Voegtlin, D. 1982: The distribution and spread of Hyadaphis tataricae (Homoptera: Aphididae) in the North-Central states with notes on its hosts, biology and origin. — Great Lakes Entomol. 15:147-152.

Received 7.XI.1991 